\title{
Regional simulations to quantify land use change and irrigation impacts on hydroclimate in the California Central Valley
}

\author{
Jiming Jin • Norman L. Miller
}

Received: 30 July 2010 /Accepted: 24 September 2010/Published online: 20 October 2010

(C) The Author(s) 2010. This article is published with open access at Springerlink.com

\begin{abstract}
In this study, the influence of land use change and irrigation in the California Central Valley is quantified using the Pennsylvania State University/National Center for Atmospheric Research fifth generation Mesoscale Model (MM5) coupled with the Community Land Model version 3 (CLM3). The simulations were forced with modern-day and presettlement land use types at $30-\mathrm{km}$ spatial resolution for the period 1 October 1995 to 30 September 1996. This study shows that land use change has significantly altered the structure of the planetary boundary layer (PBL) that affects near-surface temperature. In contrast, many land-use change studies indicate that albedo and evapotranspiration variations are the key processes influencing climate at local-to-regional scales. Our modeling results show that modern-day daily maximum near-surface air temperature (Tmax) has decreased due to agricultural expansion since presettlement. This decrease is caused by weaker sensible heat flux resulting from the lower surface roughness lengths associated with modern-day crops. The lower roughness lengths in the Central Valley also result in stronger winds that lead to a higher PBL. The higher PBL produces stronger sensible heat flux, causing nighttime warming. In addition to land use change, cropland irrigation has also affected hydroclimate processes within the California Central Valley. We generated a 10-member MM5-CLM3 ensemble simulation, where each ensemble member was
\end{abstract}

\footnotetext{
J. Jin $(\bowtie)$

Departments of Watershed Sciences and Plants, Soils, and Climate, Utah State University,

Logan, UT, USA

e-mail: jimingjin99@gmail.com

N. L. Miller

Earth Sciences Division, Lawrence Berkeley National Laboratory, Berkeley, CA, USA
}

forced by a fixed volumetric soil water content (SWC) between $3 \%$ and $30 \%$, at $3 \%$ intervals, over the irrigated areas during a spring-summer growing season, 1 March to 31 August 1996. The results show that irrigation lowers the modern-day cropland surface temperature. Daytime cooling is produced by irrigation-related evaporation enhancement. This increased evaporation also dominates the nighttime surface cooling process. Surface cooling and the resulting weaker sensible heat flux further lower the near-surface air temperature. Thus, irrigation strengthens the daytime near-surface air temperature reduction that is caused by land use change, and a similar temperature change is seen for observations over irrigated cropland. Based on our modeling results, the nighttime near-surface warming induced by land use change is alleviated by low-intensity irrigation $(17 \%<\mathrm{SWC}<19 \%)$, but such warming completely reverses to a cooling effect under high-intensity irrigation (SWC $>19 \%$ ). The land use changes discussed in this study are commonly observed in many regions of the world, and the physical processes identified here can be used to better understand temperature variations over other areas with similar land cover changes.

\section{Introduction}

Land use change and irrigation significantly affect climate and ecosystems across the world (Diffenbaugh 2009; Sacks et al. 2009; Lee et al. 2009; Lobell et al. 2006; Bonfils and Lobell 2007). A statistical analysis of the southern half of the California Central Valley was performed by Christy et al. (2006) using temperature observations for the San Joaquin Valley, where land use has changed dramatically since presettlement (circa 1860s), due to extensive agricultural expansion. Their study indicated that the daily maximum near-surface air temperature for this region exhibited a 
cooling trend over the last century. This finding is in opposition to the observed warming trends that prevail over most other regions (Hansen et al. 2006; Houghton et al. 2001; many others), suggesting that agricultural activity and associated irrigation most likely play a key role in producing this cooling trend. Christy et al. (2006) also indicated that the nighttime warming trend in the California Central Valley is likely related to irrigation. Bonfils and Lobell (2007) confirmed the daytime cooling indicated by Christy et al. (2006), but argued that their finding of nighttime warming is related to irrigation due to increased heat capacity of the soil and vegetation in the Central Valley.

Modeling studies have shown that land use change affects regional climate by altering the components in the surface energy budget (Kueppers et al. 2007; Diffenbaugh 2009). Based on the results from a general circulation model (GCM), Snyder et al. (2004) indicated that removing all temperate forest and replacing it with bare soil produce cooling in the winter and spring over tropical and boreal areas due to an increase in the surface albedo, but produce warming during the summer due to reduced evapotranspiration. If forced with a moderate amount of carbon dioxide, GCMs could produce similar results for the entire twentyfirst century (Feddema et al. 2005). These GCM predictions also indicate that the response of land use change could be overridden by a strong atmospheric circulation system such as the Asian Monsoon circulation.

Land use change will also alter other variables and fluxes within the hydrologic cycle. Costa et al. (2003) performed a data analysis over the Tocantins River basin in Brazil, where the agricultural area has expanded to $50 \%$ of the total basin area, and found that streamflow increases by more than $20 \%$ over the period of agricultural expansion, while precipitation does not show a meaningful change during the same period. This study shows that clearing natural vegetation cover (especially forests) increases surface runoff and streamflow. Guo et al. (2000) indicate that forest ecosystems help to regulate discharge water in the Yangtze River in China, where streamflow is suppressed during wet seasons, but enhanced during dry seasons.

In many areas, land cover change due to agricultural development often includes irrigation. The role of irrigated versus nonirrigated agriculture has not previously been analyzed separately in the context of climate change, and is not yet well understood. To directly address this problem, we use a sophisticated regional climate model to isolate the influence of land use change from that of irrigation to fully understand how, and to what extent, each process affects regional climate within the California Central Valley. In addition, recent studies attributed temperature change to surface albedo and evapotranspiration variations due to land use change and irrigation (e.g. Diffenbaugh 2009; Snyder et al. 2004). As we know, surface albedo and evapotranspiration directly affect the surface skin temperature. However, the temperature data used to describe climate change were mostly measured at a height of $2 \mathrm{~m}$, that is, the lower part of the atmospheric planetary boundary layer (PBL). Land use change has the potential to change the structure of the PBL and, in turn, alter the near-surface air temperature (e.g. at a height of $2 \mathrm{~m}$ ), which is often significantly different from the surface skin temperature and is partially determined by the turbulent features of the lower part of the PBL. Little work has explored how land use change affects the PBL, which is one focus of this paper.

The California Central Valley is the subject of this study. It stretches nearly $600 \mathrm{~km}$ from north to south, and 60 $100 \mathrm{~km}$ from west to east. More than half of this area has been converted to agriculture since the presettlement period. The Central Valley produces one quarter of the agricultural products in the United States, with an annual income exceeding $\$ 26$ billion and an export revenue exceeding $\$ 6.7$ billion (Wilkinson et al. 2002). Thus, understanding the climate variability in this area is critical for projecting future economic sustainability in California and the USA.

\section{Model and data}

The regional climate model used here is the nonhydrostatic fifth generation Mesoscale Model (MM5) version 3.7, developed by the Pennsylvania State University/National Center for Atmospheric Research (NCAR; Grell et al. 1994). To improve land surface characterizations, and to more accurately simulate surface and atmospheric heat flux exchange, the NCAR Community Land Model version 3 (CLM3; Oleson et al. 2004) has been coupled to MM5 and evaluated (Jin and Miller 2010). In this study, the Grell convection scheme within MM5 is chosen to parameterize cumulus clouds (Grell 1993), and the medium range forecast PBL scheme (Hong and Pan 1996) is applied to solve boundary layer processes. The microphysics scheme selected is the Simple Ice scheme developed by Dudhia (1989). The NCAR Community Climate Model version 2 radiation scheme (Hack et al. 1993) is selected for describing shortwave and longwave transfer within the atmosphere and to the surface.

CLM3 has five snow layers, one vegetation layer, and 10 soil layers (Oleson et al. 2004). In this study, we have set the total soil depth to $3.2 \mathrm{~m}$, and include a thin topsoil layer $(1.7 \mathrm{~cm})$ to efficiently capture time-evolving surface temperature variability. The heat and water flux exchange between the bottom of the canopy and the snow/soil surface are included in CLM3. Up to eight subgrid cells per model grid cell are introduced into CLM3 to better describe subgrid surface heterogeneity. An advanced surface albedo scheme 
(Dickinson et al. 1993; Bonan 1996) is adopted to accurately simulate and predict the solar radiation budget at the surface. A two-stream radiation transfer scheme (Dickinson 1983; Sellers 1985) is used in CLM3 to characterize shortwave radiation transfer within the canopy.

In MM5-CLM3 (hereafter referred to as MMC), a limited single domain with a $30-\mathrm{km}$ resolution is set with 3,776 (64×59) grid cells (Fig. 1), where the Central Valley is located near the domain center. Since the Central Valley is a very flat area, our in-house tests show that a resolution finer than $30 \mathrm{~km}$ does not give additional benefits for the simulations described in this study (figure not shown). Diffenbaugh (2009) and Kueppers et al. (2008) also discussed Central Valley land use change with a similar spatial resolution $(25-30 \mathrm{~km})$. The MMC is configured with 23 vertical sigma layers from the surface to the $100 \mathrm{hPa}$ level, to capture physical processes within the PBL to the upper atmosphere. Daily maximum and minimum surface air temperature observations (usually measured and modeled at a height of $2 \mathrm{~m}$ above the surface; hereafter referred to as Tmax and Tmin, respectively) are obtained from Christy et al. (2006), and are used here to detect temperature trends and evaluate the MMC. These observations cover the period of 1910-2003, were collected from all of the available meteorological stations located in the San Joaquin Valley, and were quality-controlled.

\section{Methodology}

The $2.5^{\circ} \times 2.5^{\circ}$ resolution National Centers for Environmental Prediction/Department of Energy Reanalysis data II
(NCEP-2; Kanamitsu et al. 2002) were used as the MMC initial and 6-h updated lateral boundary conditions. Our simulation period, 1 September 1995 through 30 September 1996, is under neutral tropical Pacific sea surface temperature (SST) conditions. During this period, without a strong forcing from the tropical Pacific, the atmospheric circulation pattern over the western US is similar to the long-term averaged pattern (figure not shown). Therefore, we chose this simulation period to avoid the potential impact of interannual climate variability on the response of land use change to the regional climate system, because such an impact has been indicated in Feddema et al. (2005). The NCEP-2 Reanalysis SST was used to initialize the MMC over the oceans and was updated every $6 \mathrm{~h}$. Two simulations with the above model settings were carried out: one driven by modern-day land use types (hereafter referred to as MOD) and the other driven by presettlement land use types (hereafter referred to as PRE). The first month of simulation from both the MOD and PRE were discarded to alleviate the effects of the initial conditions. Thus, the model settings for the two runs are exactly the same except for the land use types and associated vegetation parameters, allowing us to isolate and identify the impact of these land use changes on regional climate variability. The MOD land use types are the 24 United States Geological Survey (USGS) land use types (Fig. 1a) that was translated from the Global Land Cover Characteristics (GLCC) dataset. This dataset was developed based on the 1-km resolution Advanced Very High Resolution Radiometer (AVHRR) satellite data (Loveland et al. 2000). The PRE land types are also the 24 USGS land use types (Fig. 1b), but they were created from the

Fig. 1 Land use types for a modern and $\mathbf{b}$ presettlement times. The legend for these land use types is given in Table 1. The observations used in this study are for the San Joaquin Valley as indicated in the figure

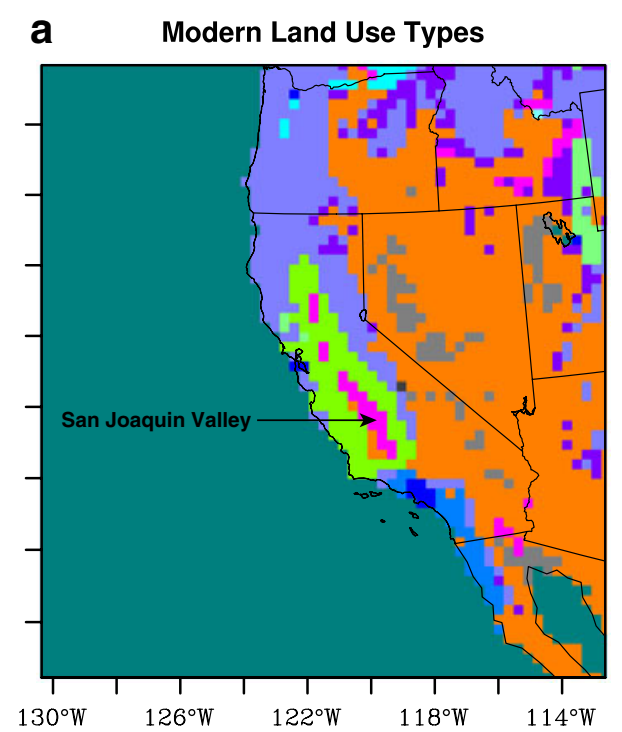

b Presettlement Land Use Types

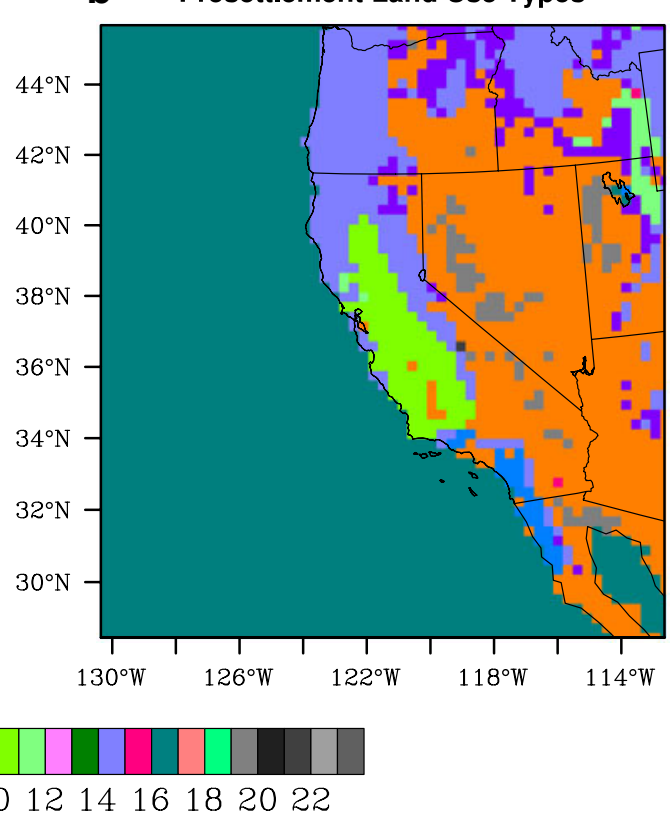


Olson Global Ecosystems version of the GLCC data (Olson 1994).

In the first part of this study, we focus only on land use change in the Central Valley, where there are $20 \mathrm{MMC}$ grid cells at $30-\mathrm{km}$ resolution with such changes. In the MOD run, the land use types for all of these 20 grid cells are defined as crop (type 3 in Fig. 1a and Table 1), but in the PRE run, the land types for these grid cells are defined as savanna (type 10 in Fig. $1 \mathrm{~b}$ and Table 1). The GLCC land use types represent only the dominant vegetation type per grid cell. But with subgrids configured in CLM3, the dominant vegetation type is often associated with secondary land use types with relatively smaller coverage per grid cell. Based on the subgrid land use type classification in our version of CLM3 that was adopted from Bonan (1996), the crop type covers $85 \%$ of the grid cell area in the MOD run, with the remaining $15 \%$ area covered by bare soil (Table 2). In the PRE run, savanna occupies $70 \%$ of the area of each grid cell, and interrupted broadleaf deciduous tropical trees (for simplicity referred to hereafter as tree) covers the remaining $30 \%$. The roughness lengths for the land use types mentioned above are listed in Table 2, and their leaf area indices (LAIs), excluding bare soil, were derived from the $16-\mathrm{km}$ resolution AVHRR satellite data, and are discussed in detail in Section 4.1.

Table 1 USGS vegetation categories
1. Urban and built-up land
2. Dryland cropland and pasture
3. Irrigated cropland and pasture
4. Mixed dryland/irrigated cropland and pasture
5. Cropland/grassland mosaic
6. Cropland/woodland mosaic
7. Grassland
8. Shrubland
9. Mixed shrubland/grassland
10. Savanna
11. Deciduous broadleaf forest
12. Deciduous needleleaf forest
13. Evergreen broadleaf forest
14. Evergreen needleleaf forest
15. Mixed forest
16. Water bodies
17. Herbaceous wetland
18. Wooded wetland
19 . Barren or sparsely vegetated
20. Herbaceous tundra
21. Wooded tundra
22. Mixed tundra
23. Bare ground tundra
24. Snow or ice

Table 2 Land use type and associated coverage and roughness length in the MOD and PRE runs over the Central Valley

\begin{tabular}{llllll}
\hline GLCC land use type & \multicolumn{2}{l}{ MOD } & & & \multicolumn{2}{l}{ PRE } \\
\cline { 2 - 3 } \cline { 5 - 6 } & Type 3 & & & Type 10 & \\
\hline Land use & Crop & Bare soil & & Savanna & Tree \\
Cover & $85 \%$ & $15 \%$ & & $70 \%$ & $30 \%$ \\
Roughness & $0.06 \mathrm{~m}$ & $0.01 \mathrm{~m}$ & & $0.06 \mathrm{~m}$ & $0.99 \mathrm{~m}$ \\
\hline
\end{tabular}

Globally, agricultural expansion mostly changes grassland and forest areas to cropland (Foley et al. 2005), and cropland is often associated with more bare soil due to having stronger seasonal variation than natural vegetation cover. Thus, the land use change discussed in this study and its related physical processes are representative.

Irrigation is typically applied in the Central Valley when the volumetric soil water content (SWC) is below the field capacity. These operational irrigation practices occur primarily during the California warm season, because during this time there is insufficient rainwater available for growing crops. However, irrigation practices vary locally by vegetation and soil types, farming practices, and water availability; hence, it is unrealistic to believe that irrigation can be embedded in regional climate model prediction schemes without significant uncertainties. At the same time, the SWC in this region has not been extensively measured, making it very difficult to incorporate accurate SWC observations into a climate model for the Central Valley.

Therefore, in the second part of this study, we investigate how irrigation affects climate in the Central Valley using a 10 -member ensemble simulation. Each ensemble member is forced with a different fixed SWC for the entire soil column, reflecting a range of possible irrigation-controlled SWC levels. The lowest fixed SWC was $3 \%$, and was increased by increments of $3 \%$ until it reached $30 \%$, resulting in 10 ensemble simulations. Each simulation starts on 1 March 1996 and ends on 31 August 1996, representing a simulation of the 6 months during which irrigation typically occurs in the Central Valley. All of the ensemble simulations (henceforth, the 10 MOD ensemble simulations will be referred to as M10) were initialized on 1 March 1996, using results from the 1 September 1995-30 September 1996 MOD run from the first part of this study. Table 3 lists five types of soil among the 20 grid cells covering the Central Valley cropland, showing that the most common soil types are sandy loam (eight cells) and clay (six cells). The cell number, porosity, and field capacity for each type of soil are also listed in Table 3. The maximum field capacity is $27 \%$ SWC for clay, and the minimum is $6 \%$ SWC for sand. Thus, the SWC values for our M10 simulations encompass all possible values for the field 
Table 3 Soil types, cell number, porosity, and field capacity within the Central Valley

\begin{tabular}{|c|c|c|c|c|c|}
\hline Soil type & 13 & 12 & 9 & 3 & 1 \\
\hline Name & Organic material & Clay & Clay loam & Sandy loam & Sand \\
\hline Cell number & 2 & 6 & 3 & 8 & 1 \\
\hline Porosity & 0.44 & 0.46 & 0.45 & 0.40 & 0.37 \\
\hline Field capacity & 0.16 & 0.27 & 0.20 & 0.12 & 0.06 \\
\hline
\end{tabular}

capacity in the Central Valley, a parameter that is often used to manage irrigation systems.

\section{Results}

Here, we present a discussion of the impacts of changes in land use types in the Central Valley by evaluating the LAIs, observed temperature trends, Tmax, Tmin, and the surface energy budget. This is followed by a discussion of the MOD ensemble simulations and the respective changes in Tmax, Tmin, and the surface energy budget.

\subsection{Leaf area indices in the Central Valley}

The vegetation LAI is an important parameter for understanding the impacts of land use change. In order to realistically describe LAI variations over croplands in the Central Valley, we have assimilated an 18-year monthly average $16-\mathrm{km}$ resolution remotely sensed, AVHRR LAI dataset into MMC to represent monthly LAI climatology. These monthly LAIs averaged over the Central Valley show that there are two major crop-growing seasons, with LAI peak values in March (4.0) and July (4.8; Fig. 2a).

Leaf area index data for the presettlement period are very difficult to find in existing historical records. Thus, we use the AVHRR data to derive the LAI data for the area of the Central Valley that was covered with savanna grassland and deciduous trees based on the Olson land use types (Olson 1994). This LAI derivation assumes that the seasonal climate pattern during the presettlement period is the same as that in the present. We obtained LAI data for savanna grassland and tropical deciduous broadleaf trees for an area proximal to the Central Valley (32 N $125 \mathrm{~W}, 45 \mathrm{~N} 105 \mathrm{~W}$ ) where there is a seasonal climate pattern similar to that over the cropland regions of the Central Valley. We then use these monthly LAI values for savanna grassland and tropical deciduous broadleaf trees to approximate the LAIs during presettlement (Figs. $2 b$ and c). Figure $2 b$ shows the monthly variation of the savanna LAI, where the maximum value (5.0) is in March, primarily due to strong precipitation, the minimum value (1.9) is in December, and the mean annual value is 3.2. The tropical deciduous broadleaf tree type is shown to have high LAI values ranging from 2.9 in January to 5.6 in June, with a mean annual value of
4.4. The maximum value of the LAI occurs during the warm and dry season, which implies that root water suction from the deep underground plays a strong role in supplying water for these deep-rooted trees.

The LAI data were input into MMC for the Central Valley region for both the MOD and PRE runs. The LAIs of the crops were assimilated into the MOD run, and the
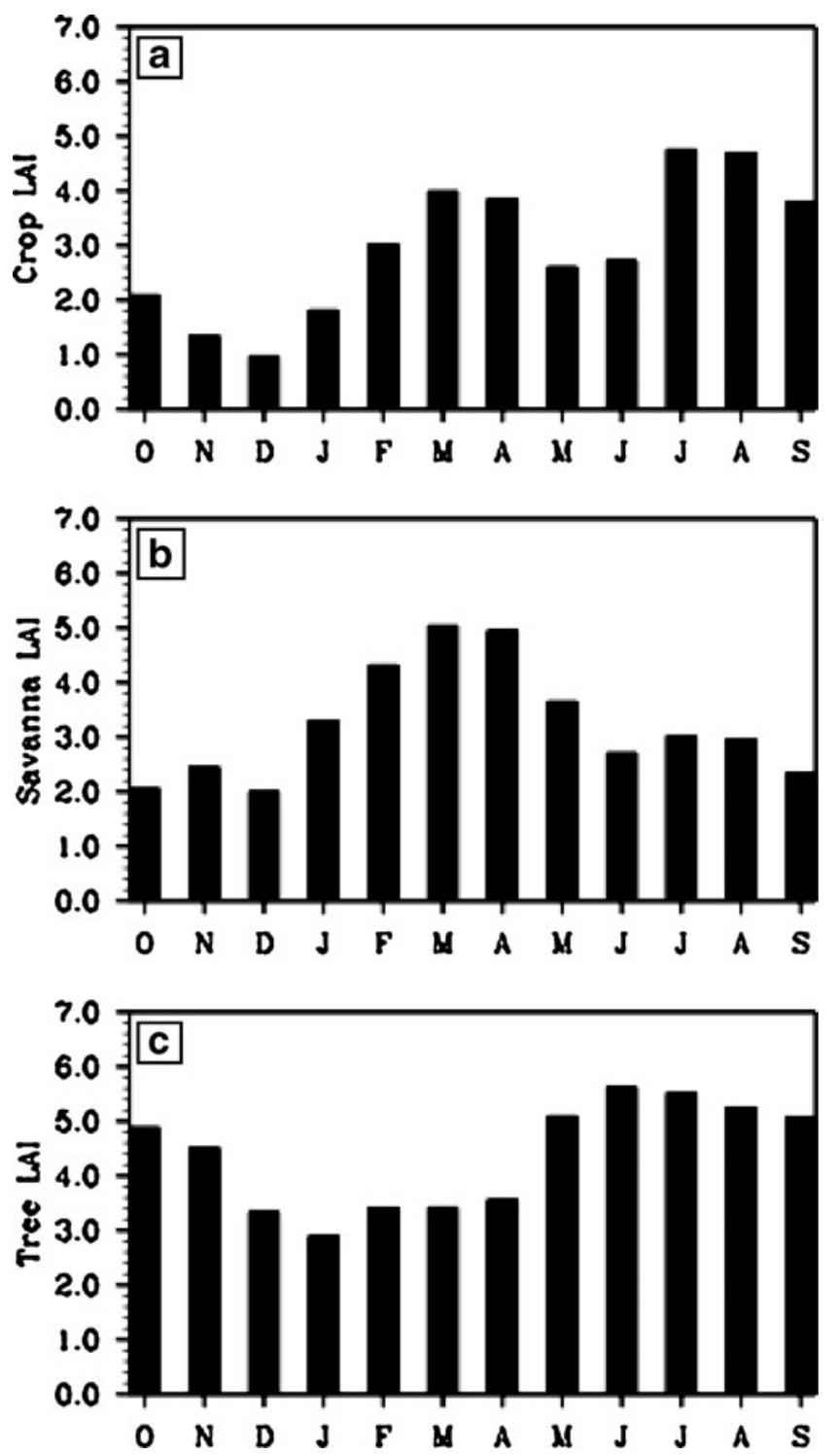

Fig. 2 Monthly AVHRR satellite LAIs of crop, savanna, and tropical deciduous tree for the California Central Valley averaged over 19832000 
LAIs of the savanna and trees were assimilated into the PRE run. In the M10 ensemble simulations, the modern crop LAI data were used for the Central Valley in the same fashion as in the MOD run.

\subsection{Observed temperature trends over the Central Valley}

Numerous analyses of observed temperatures have confirmed that global warming is occurring, with a global mean $0.60^{\circ} \mathrm{C}$ increase for the last three decades and a $0.80^{\circ}$ $\mathrm{C}$ increase for the last century (Hansen et al. 2006). On a regional scale, there are variations in the rate of warming, but most studies point to the California Central Valley as a region that is experiencing warming as a result of climate change (e.g., Hayhoe et al. 2004). Contrary to these studies, Christy et al. (2006) evaluated Tmin and Tmax rate changes using a dataset starting in the late nineteenth century, and found a cooling trend in Tmax for the San Joaquin Valley in the southern part of the Central Valley (Fig. 1). Figure 3 is similar to that in Christy et al. (2006), but shows the 94year period 1910-2003, which has higher quality data than that available from earlier times. The temperature trends in Fig. 3 indicate that Tmax has a negative (cooling) trend in all seasons (dark bars), with the strongest negative trend in the summer $\left(-0.30^{\circ} \mathrm{C} /\right.$ decade $)$, and the weakest trend in the winter $\left(-0.01{ }^{\circ} \mathrm{C} /\right.$ decade $)$. However, Fig. 3 shows that Tmin has a positive trend for all seasons (gray bars), and is consistent with the observed global warming trend. The fall and summer Tmin trends are 0.32 and $0.29^{\circ} \mathrm{C} /$ decade, respectively, but the winter and spring trends are 0.21 and $0.18^{\circ} \mathrm{C} /$ decade.

Many factors may be involved in these differences in the rate of temperature change such as carbon-induced warming, land use change, irrigation, and atmospheric aerosols (Karl et al. 1993; Qian et al. 2003). In this study, the effects of land use change and irrigation on temperature changes are specifically focused. Figure 3 shows that the magnitudes of the Tmax and Tmin trends in the summer are

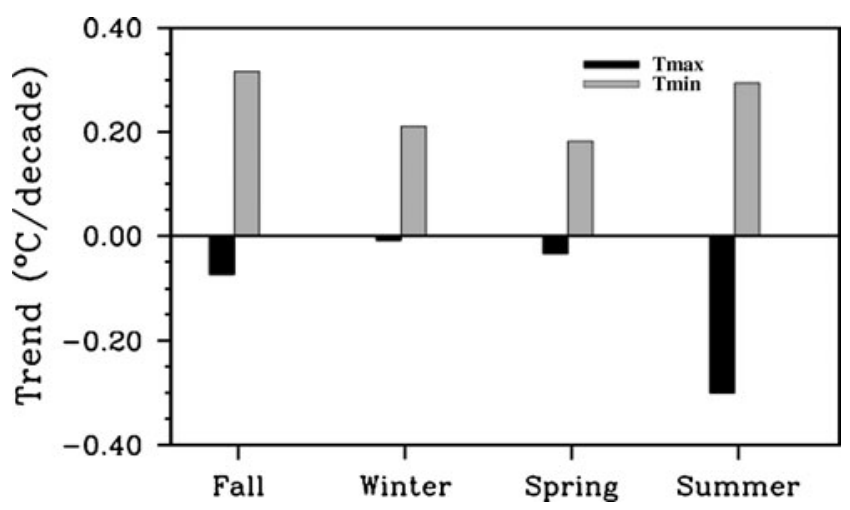

Fig. 3 Observed seasonal Tmax (dark bars) and Tmin (gray bars) trends over the San Joaquin Valley for 1910-2003 stronger than in the winter, and coincide with summer agricultural activities. This coincidence implies that these trends can be affected by the land use change from natural vegetation cover to irrigated crops. In this part of our study, we investigate the associations of these temperature changes with land use change and irrigation using MMC, and we quantify the detailed physical processes that generate such temperature variations.

\subsection{Evaluation of MMC over the agricultural area in the Central Valley}

The MMC model has been fully evaluated by Jin and Miller (2010) and is applied here along with observations from the agricultural area in the San Joaquin Valley to further evaluate its performance in temperature simulation. The simulated Tmax and Tmin are compared with observations (Fig. 4). These observations were measured at seven meteorological stations within the San Joaquin Valley (station information is illustrated in Table 4). The observations shown in Fig. 4 are the averages over these seven stations, and the simulations are the averages over the seven model grid cells in which the stations are located.

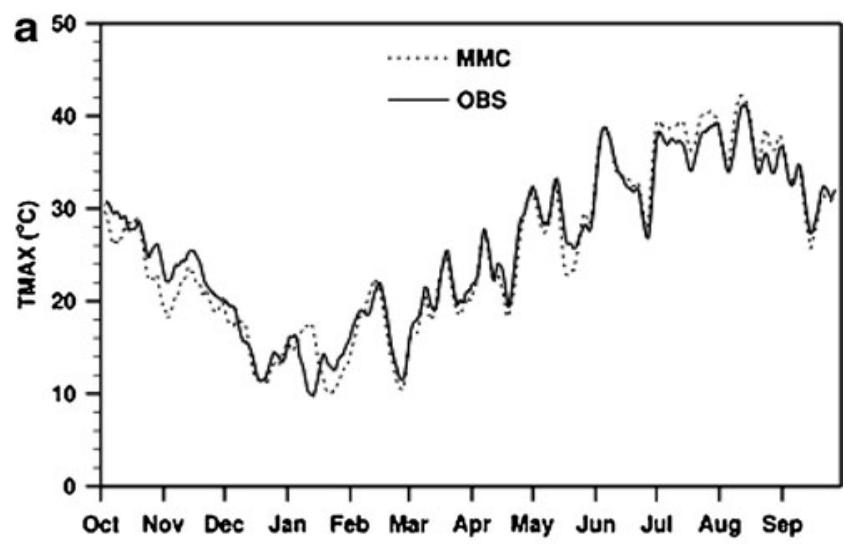

b 24

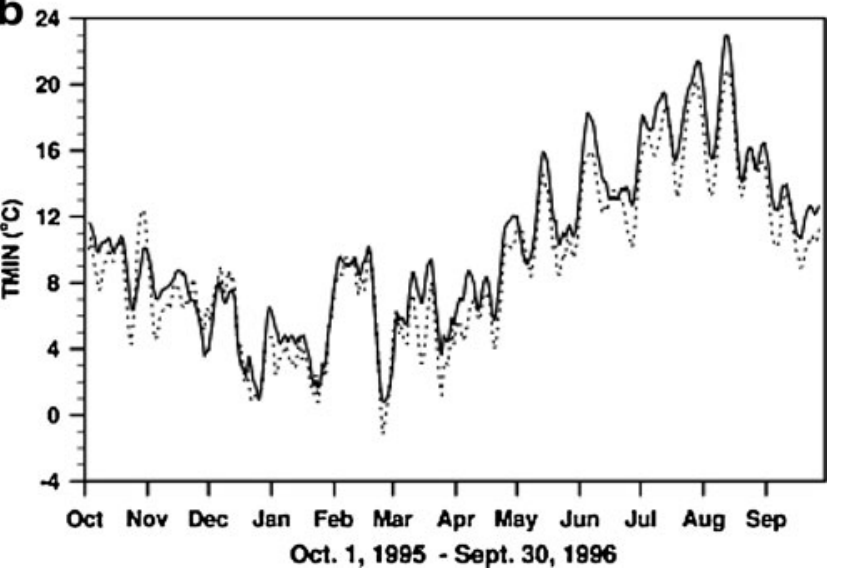

Fig. 4 Comparison of observed and simulated daily a Tmax and b Tmin over the San Joaquin Valley from 1 October 1995 to 30 September 1996 
Table 4 Meteorological stations and related information for the San Joaquin Valley

\begin{tabular}{lcccc}
\hline Station name & Station ID & Latitude $\left({ }^{\circ} \mathrm{N}\right)$ & Longitude $\left({ }^{\circ} \mathrm{W}\right)$ & Elevation $(\mathrm{m})$ \\
\hline Five Points 5 SSW, CA & 043083 & 36.37 & 120.15 & 27 \\
Fresno Air Terminal, CA & 043257 & 36.78 & 119.72 & 31 \\
Hanford, CA & 043747 & 36.30 & 119.65 & 23 \\
Lindsay, CA & 044957 & 36.20 & 119.05 & 39 \\
Los Banos, CA & 045118 & 37.05 & 120.87 & 11 \\
Madera, CA & 045233 & 36.95 & 120.03 & 25 \\
Merced Municipal Airport, CA & 045532 & 37.28 & 120.52 & 14 \\
\hline
\end{tabular}

These seven cells are also among the 20 grid cells that encompass the entire Central Valley cropland area. Figure 4 indicates that MMC reproduces the variance of Tmax and Tmin reasonably well over the San Joaquin agricultural area. The correlation coefficient between the daily observed and simulated Tmax is 0.97 , and that between the daily observed and simulated Tmin is 0.93 , with both coefficients far above the $99 \%$ Student's $t$ test significance level. Figure 4 also shows that MMC produces a cold bias, where the averaged Tmax bias is $-0.31^{\circ} \mathrm{C}$, and the averaged Tmin bias is $-1.0^{\circ} \mathrm{C}$. However, these cold biases could be significantly reduced by calculating the temperature difference between presettlement and modern times, which is the primary focus of this study.

Moreover, the average temperature of only the seven grid cells within the San Joaquin Valley is evaluated here. The quality of the temperature over the remaining 13 cells out of the 20 in the Central Valley is not examined due to a lack of high-quality observations, and because these 13 cells are mostly located in the Sacramento Valley, the northern part of the Central Valley. However, a 0.99 correlation coefficient is found between the averaged temperature over these 13 cells and that over the seven cells in the San Joaquin Valley in the southern Central Valley. This high correlation indicates that the climate regimes controlling the northern and southern Central Valley are similar under the neutral tropical Pacific SST conditions, which is also described in Jin et al. (2006). Thus, we can believe that MMC is able to reasonably simulate the temperature variations over the northern Central Valley. In the following sections, MMC is used to better understand these observed temperature trends and to quantify the role of land use change and irrigation in the temperature changes over the entire Central Valley.

\subsection{Impact of land use change on local temperature in the Central Valley}

\subsubsection{Tmax}

As mentioned above, land use types in the Central Valley have changed from savannas and trees (type 10) to crops (type 3) since presettlement, as defined in Table 2. These changes were inputted into MMC using the GLCC land use type classification for the Central Valley. Figure 5a shows MMC-simulated Tmax differences between the MOD and PRE for all four seasons averaged over the Central Valley. The ground surface skin temperature corresponding to Tmax is defined here as Tgm, and is shown in Fig. 5b. Tgm is introduced here to fully understand Tmax variations and to define its relationship with the surface energy balance. Figure 5 a indicates that Tmax decreases in the Central Valley over all four seasons in the MOD run, with the strongest reduction $\left(-0.55^{\circ} \mathrm{C}\right)$ occurring in winter. Tgm behaves differently from Tmax: in the winter Tgm decreases, while it increases during the other three seasons. To physically understand these
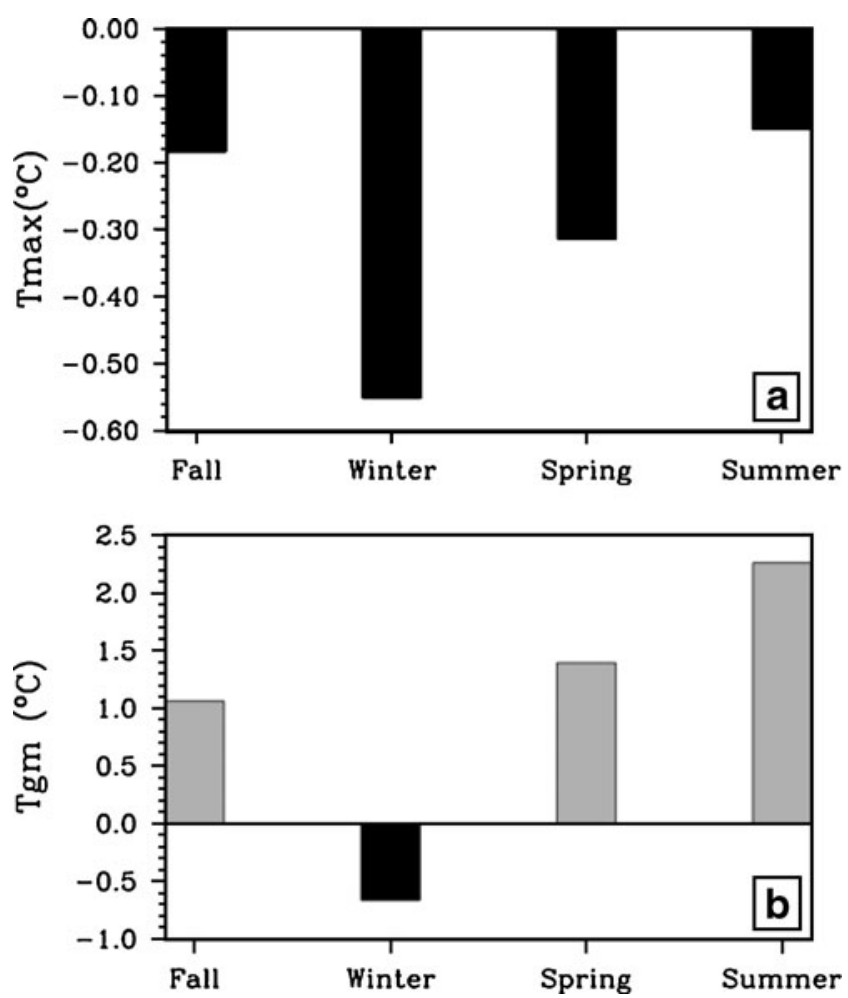

Fig. 5 Seasonal daily a Tmax and b Tgm differences between the MOD and PRE runs (MOD-PRE) for 1995 and 1996 
temperature differences, the surface energy budget equation is examined:

$$
(1-\alpha) \mathrm{SW} \downarrow+\mathrm{LWNET}-\mathrm{LHF}-\mathrm{SHF}-\mathrm{GF}=0
$$

where $\alpha$ is the surface albedo, SW $\downarrow$ is downward solar radiation, LWNET is the net longwave radiation at the surface, LHF is the latent heat flux, SHF is the sensible heat flux, and GF is the ground heat flux (positive is downward). Table 5 lists the changes of the variables in this equation between the two runs, indicating that at Tmax, the strongest changes between the MOD and PRE runs are the sensible heat flux and surface net solar radiation. The sensible heat flux decreases during all four seasons in the MOD run, and tends to maintain energy at the surface, increasing the surface temperature and contributing to the Tgm increases in the spring, summer, and fall. The net surface solar radiation decreases, and tends to reduce Tgm. However, the decrease in sensible heat flux dominates the reduction in net solar radiation over the entire year. Thus, the sensible heat flux is more dominant than the effect of net solar radiation in the spring, summer, and fall, resulting in the increase in Tgm. The reduction in net solar radiation has indeed played a role in the decrease in the winter Tgm. At the same time, the surface loses energy in the MOD run through the increase of $11 \mathrm{Wm}^{-2}$ in surface latent heat flux, as compared to that in the PRE run. Thus, net solar radiation combined with latent heat flux counters the sensible heat flux contribution, leading to the decrease in the winter Tgm.

The lower net surface solar radiation in the MOD run results from the higher surface albedo in the spring, summer, and fall, when the surface albedo slightly increases by $0.01-0.02$, which contributes to the $10-16 \mathrm{Wm}^{-2}$ net solar radiation reduction. In the MOD run, the total area for bare soil within the Central Valley is $2,835 \mathrm{~km}^{2}$, based on the $15 \%$ coverage (Table 2) in each of these grid cells. However, in the PRE run no explicit bare soil coverage is configured in MMC for land use type 10 (savanna and tree). Thus, the slight albedo increase is largely attributed to the bare soil fraction in the MOD run, where soil albedo is higher than canopy albedo. During winter, the albedo does not change, but the net solar radiation decreases by $20 \mathrm{Wm}^{-2}$. The radiation reduction is due to weakened downward solar radiation in the MOD run, resulting from the cloud fraction that increased by $\sim 3 \%$ as compared to the PRE run.

The increase in cloud fraction is caused by stronger increases in the latent heat flux $\left(11 \mathrm{Wm}^{-2}\right)$ in the MOD run. During winter, strong precipitation increases the SWC in the Central Valley in both the MOD and PRE runs (figure not shown). However, due to the cold winter temperatures, canopy photosynthesis is weak or nonexistent, implying that surface evaporation is largely from the areas of bare soil. With about $15 \%$ more bare soil exposed to the air in the MOD run than in the PRE run, the winter surface evaporation in the MOD run is stronger. During the other three seasons, despite the higher surface temperatures, evaporation in the MOD run with smaller canopy coverage is weaker than in the PRE run, implying that transpiration from the canopy is the dominant component of the total evaporation.

The decrease in sensible heat flux in the MOD run is attributed to the lower roughness lengths in the Central Valley (Table 2). Thus, a single MOD grid cell has an averaged roughness length that is much lower than a single PRE grid cell in this region. The lower roughness length suppresses the upward sensible heat flux in the MOD run. The weakening of the sensible heat flux represents a decrease in energy supply to the atmosphere from the surface, and is a key reason for the decreased Tmax in the MOD run (Fig. 5a). According to the theory of the PBL, a lower surface roughness length tends to lower the PBL height. Figure 6 shows that the lower roughness length in the MOD run decreases the PBL height by more than $90 \mathrm{~m}$ over the four seasons when compared to that in the PRE run. The maximum PBL reduction $(-173 \mathrm{~m})$ occurs in the summer. The lower PBL height indicates weakened turbulence and thus, reduced upward sensible heat flux.

Furthermore, ground heat flux is significantly larger in spring in the MOD run than in the PRE run (a difference of $12 \mathrm{Wm}^{-2}$; Table 5). With more bare soil exposed in the
Table 5 Changes between the MOD and PRE runs for the variables in the energy balance equation [Eq. (1) in the text] at Tmax and Tmin over four seasons

The unit for all the variables is $\mathrm{Wm}^{-2}$, except for $\alpha$ which is dimensionless

\begin{tabular}{llllllll}
\hline & & $\alpha$ & $(1-\alpha)$ SW $\downarrow$ & LWNET & SHF & LHF & GF \\
\hline Tmax & Fall & 0.01 & -14 & -5 & -15 & -5 & 1 \\
& Winter & 0.00 & -20 & 5 & -27 & 11 & 1 \\
& Spring & 0.01 & -10 & -7 & -20 & -9 & 12 \\
\multirow{5}{*}{ Tmin } & Summer & 0.02 & -16 & -12 & -24 & -6 & 2 \\
& Fall & N/A & 0 & 1 & 5 & 0 & -4 \\
& Winter & N/A & 0 & -1 & 6 & 0 & -7 \\
& Spring & N/A & 0 & -3 & 9 & 0 & -12 \\
& Summer & N/A & 0 & 2 & 8 & 0 & -6 \\
\hline
\end{tabular}




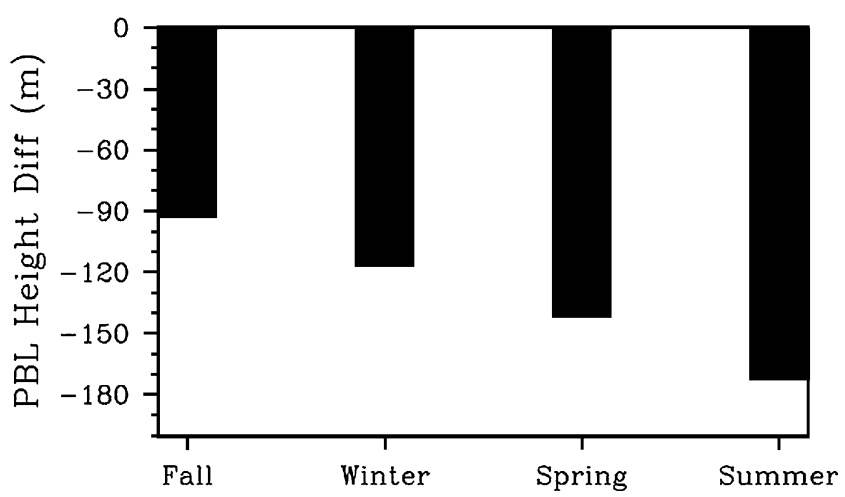

Fig. 6 PBL height difference between the MOD and PRE runs (MOD-PRE) at Tmax for 1995 and 1996

MOD run, the soil surface receives more radiation energy, potentially leading to a larger ground heat flux. In addition, springtime precipitation over the Central Valley increases SWC, which further produces a large soil thermal conductivity, allowing heat flux to readily enter the soil. Therefore, the stronger spring ground heat flux in the MOD run is due to the larger fraction of wet soil. However, wet soil from strong precipitation also occurs in winter, but ground heat flux is only $1 \mathrm{Wm}^{-2}$ larger in the MOD run than in the PRE run. This small increase is most likely caused by weaker incoming radiation in winter, which decreases by $20 \mathrm{Wm}^{-2}$ in the MOD run due to the larger cloud fraction originating from stronger surface evaporation, as mentioned above.

\subsubsection{Tmin}

Figure 7 indicates that in the MOD run, as compared with the PRE run, the Tmin averaged over the Central Valley increases by more than $0.40^{\circ} \mathrm{C}$ in the fall, and by approximately $1{ }^{\circ} \mathrm{C}$ in the winter and spring, while in the summer, Tmin shows little change $\left(\sim 0.08^{\circ} \mathrm{C}\right)$. At Tmin, the corresponding ground surface skin temperature, Tgn, increases by $0.66^{\circ} \mathrm{C}$ and $0.88^{\circ} \mathrm{C}$ in winter and spring, respectively. Tgn changes very little in the fall and summer.

Table 5 shows that the major differences between the MOD and PRE runs occur in sensible heat flux and ground heat flux at Tmin, where the sensible heat flux becomes stronger in all seasons for the MOD run, while ground heat flux becomes weaker. The increased sensible heat flux in the MOD run tends to reduce Tgn. Thus, the stronger sensible heat flux is not a reason for the increased Tgn in winter and spring in the MOD run, but it is the reason for the higher Tmin in fall, winter and spring, when sensible heat flux increases by $5-9 \mathrm{Wm}^{-2}$, providing more energy to the near-surface air.

As mentioned previously, lower roughness length tends to reduce the PBL height. Therefore, it is surprising to see in Fig. 8a that the PBL height is higher in all seasons with the lower roughness length at the Tmin. The maximum increase is nearly $30 \mathrm{~m}$, which occurs in the spring. This PBL height increase implies that some other factors are likely involved in affecting the PBL height. Further investigation finds that the wind speed in the lower PBL is an important factor that increases the PBL height (Fig. 8b). With a flatter surface in the MOD run in the Central Valley, the wind speed is expected to be higher than that in the PRE run, resulting in stronger turbulence and thus, an increased PBL height. Figure $8 \mathrm{~b}$ shows that the wind speed in the MOD run increases by $0.075-0.15 \mathrm{~m} / \mathrm{s}$ in fall, winter, and spring, representing a $4-7 \%$ wind speed increase over that in the PRE run. During the summer, the wind speed increases very little, while the PBL height changes the least during the same time $(<10 \mathrm{~m})$.

The PBL in the MOD run is expected to be more stable with the lower roughness length than it is in the PRE run. However, the lower roughness length causes faster winds at the same time, resulting in stronger turbulence and decreased PBL stability. The net effect is an increased PBL height in the MOD run that results in a stronger sensible heat flux and thus, near-surface warming in the evening.

During the night, ground heat flux comes to the surface from deeper soil layers in both the MOD and PRE runs, compensating for the energy loss due to outgoing longwave radiation. The smaller ground heat flux in the MOD run
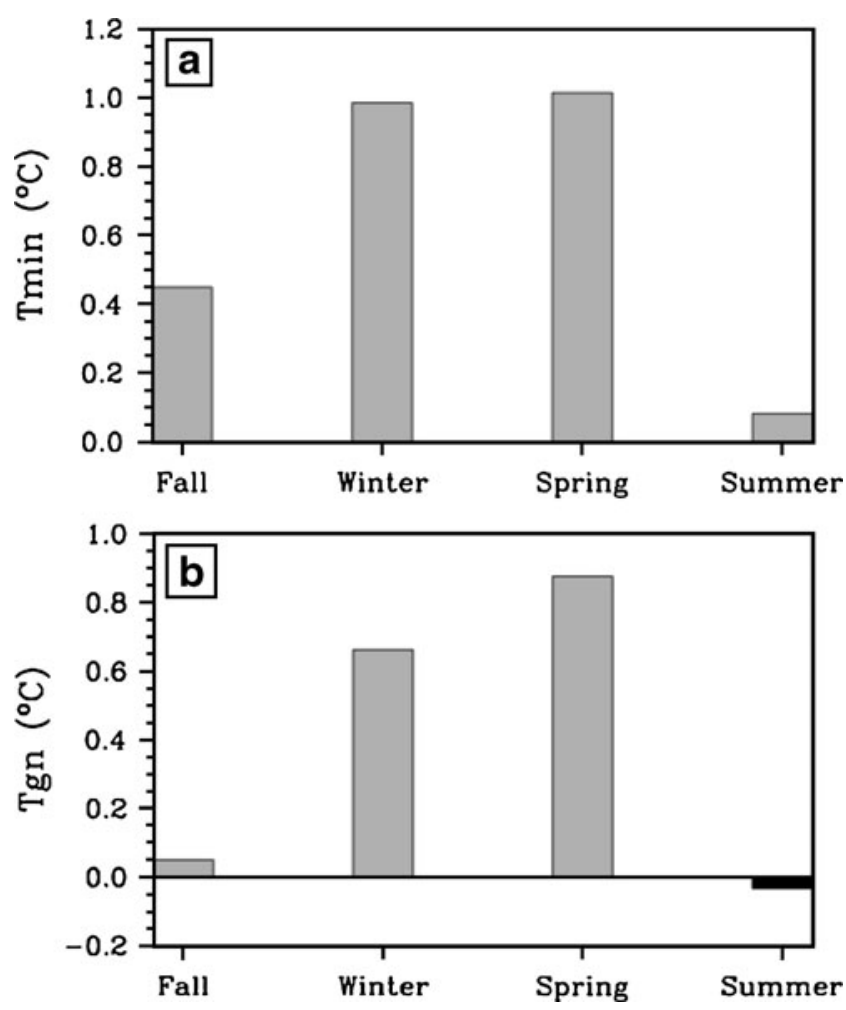

Fig. 7 Seasonal daily a Tmin and b Tgn differences between the MOD and PRE runs (MOD-PRE) for 1995 and 1996 

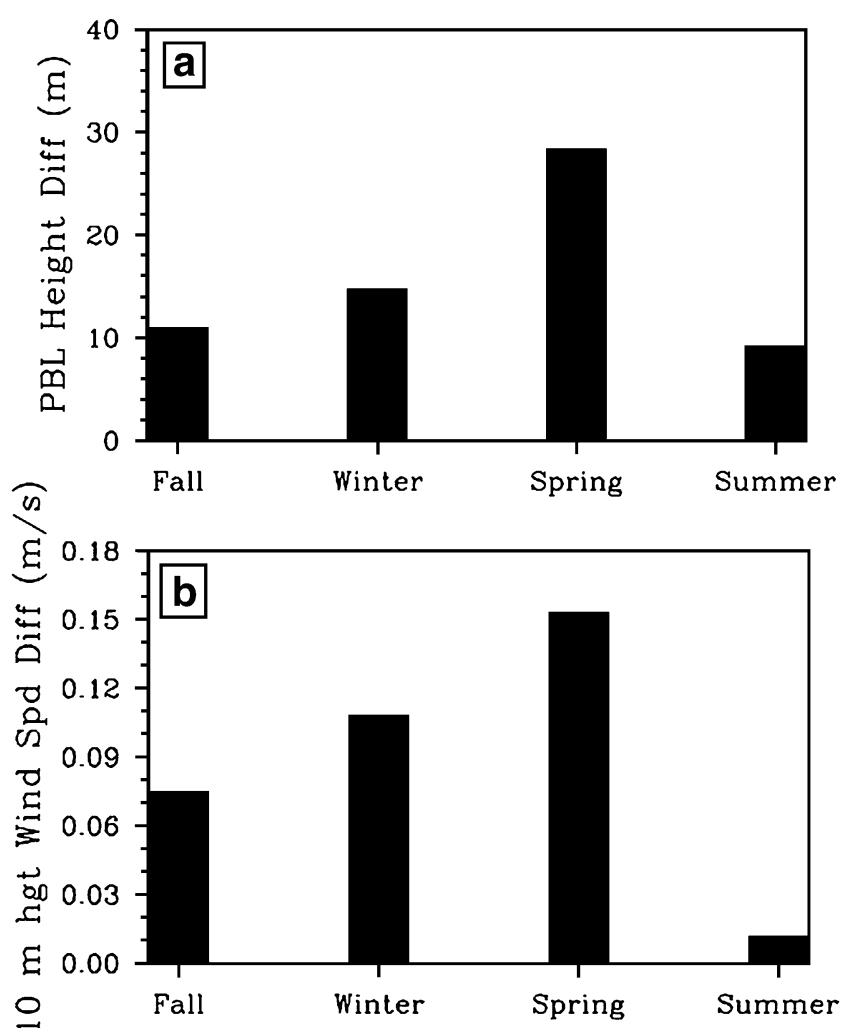

Fig. 8 Differences in a PBL height and b 10-m height wind speed between the MOD and PRE runs (MOD-PRE) at Tmin for 1995 and 1996

indicates that more energy is supplied from deeper soil to the surface and warms the surface. In the MOD run, the absolute evening ground heat flux that comes to the surface increases by $4-12 \mathrm{Wm}^{-2}$ (upward is negative) over the four seasons. The ground heat flux change is caused by changes in soil temperature gradient. In the MOD run, there is a larger fraction of bare soil exposed to the air, resulting in a significantly greater energy exchange between the soil surface and the atmosphere than in the PRE run. These greater energy exchanges could result in a higher soil temperature gradient regardless of its direction, leading to higher absolute ground heat fluxes in the MOD run.

Based on the above analysis, lower roughness length leads to faster near- surface winds in the MOD run and thus increases the PBL height. A stronger sensible heat flux is seen in the higher PBL, resulting in near-surface warming during the night.

\subsection{The impact of irrigation on the local climate} using ensemble simulations

In addition to the change from natural vegetation cover to cropland in the California Central Valley since presettlement, irrigation has also expanded and is carried out extensively during the late spring and summer dry seasons.
This part of our analysis explores the impact of irrigation on the local climate. However, SWC variations due to irrigation are largely uncertain, watering amounts and times are not predictable, and quality-controlled SWC observations are not available for the most part in this area. To fully understand the impact of irrigation on the climate and separate this impact from that of land use change, MOD M10 simulations, forced with a range of possible SWC values, were performed and compared to the single MOD where the SWC changes were based on the mass balance equation in the model. Each ensemble simulation of the M10 was initialized with the results from the MOD run that began on 1 March 1996 and ended on 31 August 1996. Detailed information about model settings for the M10 simulations was discussed for the MOD simulation in Section 3, and the following subsections provide an analysis of how changes in SWC affect Tmax, Tmin, and the surface energy budget.

\subsubsection{Tmax}

Figure 9 shows the temperature and heat flux differences between the M10 simulations (each with fixed SWC ranging from $3 \%$ to $30 \%$ ), and the MOD simulation (solid curve). These results are averages for the 1 March-31 August 1996 simulation period. Figure 9a shows that Tmax averaged over the Central Valley decreases almost linearly with increasing SWC. Tgm displays a similar change, decreasing by nearly $7^{\circ} \mathrm{C}$ when the SWC reaches $30 \%$ (Fig. 9b). Our analysis also shows that sensible, latent, and ground heat fluxes change significantly when the SWC varies (Figs. 9c, d, and e), while net surface solar radiation and longwave radiation change very little with changing SWC (figures not shown). Sensible heat flux reduces proportionally with the decrease in Tgm. The decrease in sensible heat flux further lowers Tmax, leading to a reduction of approximately $2.5^{\circ} \mathrm{C}$ when the SWC is at the highest specified amount (30\%). The latent heat flux difference between the M10 runs and the MOD run increases from $0 \mathrm{Wm}^{-2}$ to $120 \mathrm{Wm}^{-2}$ with increasing SWC from $3 \%$ to $30 \%$, while the Tgm difference decreases from about $-1^{\circ} \mathrm{C}$ to $-7^{\circ} \mathrm{C}$. Thus, surface evaporation is clearly a reason for the Tgm reduction. Ground heat flux is also amplified by about $15 \mathrm{Wm}^{-2}$ when the soil changes from the driest condition (3\%) to the wettest $(30 \%)$ in our M10 simulations. This amplification results from the increased soil thermal conductivity with increasing SWC. However, the ground heat flux is still lower for all the M10 runs than it is for the MOD run, which is explained later.

The vertical line in Fig. 9 is the position of the averaged 1-m SWC during the MOD run for March through August 1996 , and is $17 \%$. The region in the M10 minus MOD curve where the SWC is $17 \%$ or greater is defined here as 

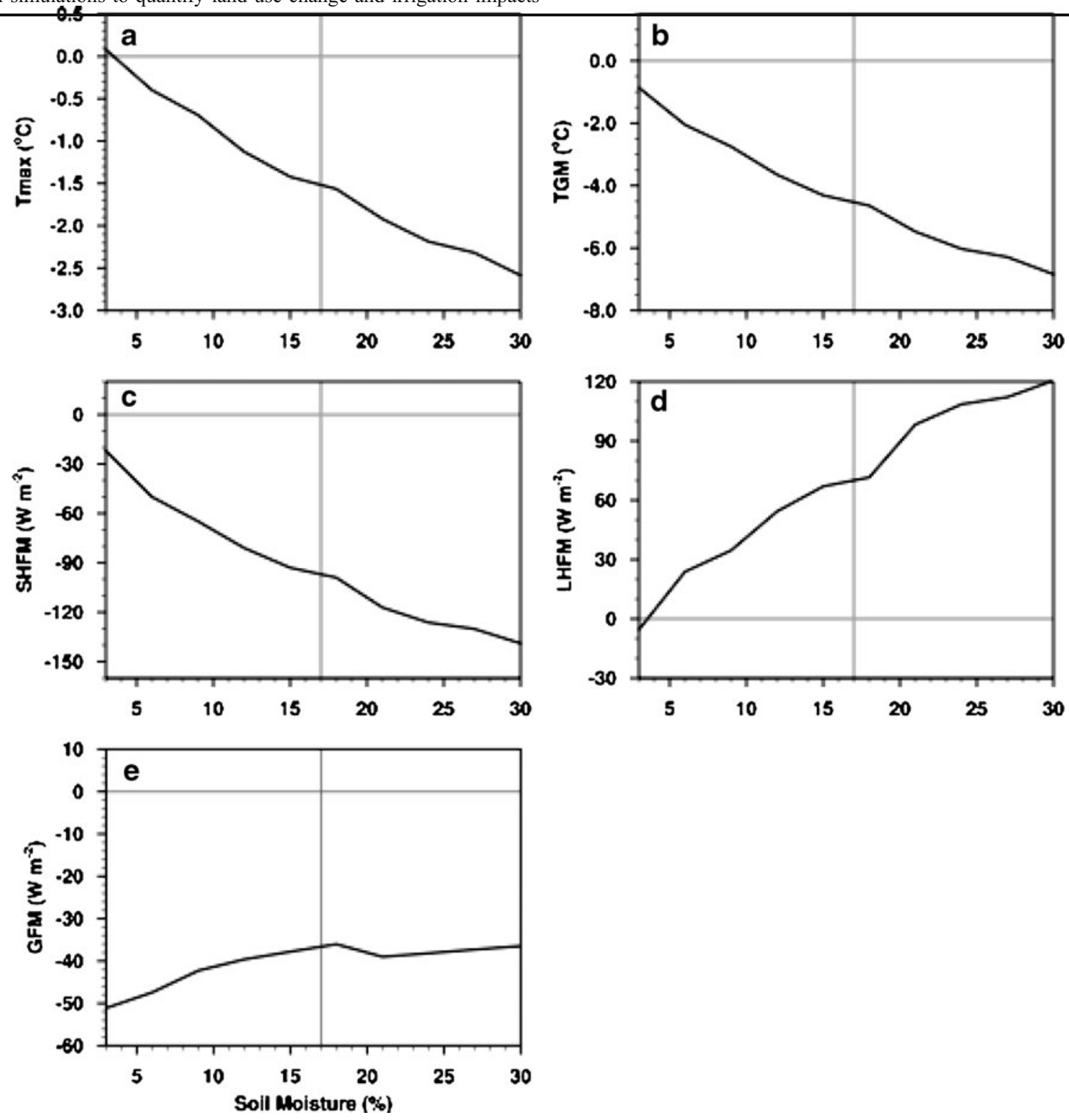

Fig. 9 Temperature and heat flux differences versus SWC between the M10 ensemble simulations and the MOD simulation (M10-MOD) averaged over spring and summer in 1996. a Tmax, b Tgm, c sensible

heat flux, $\mathbf{d}$ latent heat flux, e ground heat flux. The solid vertical line is the position for the $1-\mathrm{m}$ averaged SWC in the MOD run over the same period

the "irrigation zone." In Figure 9, we found that even if the M10 and MOD simulations have the same SWC, the variables from the M10 simulations still have large differences compared to those in the MOD run. To understand this phenomenon, the averaged vertical profile of the SWC during the spring and summer in the MOD simulation is plotted in Fig. 10. This figure indicates that the near surface SWC values are $6 \%$ lower than the averaged value (17\%), which greatly reduces soil surface evaporation. When the averaged SWC over the soil column in both the MOD run and M10 runs is at $17 \%$, the near-surface M10 soil is wetter, producing higher soil thermal conductivity. This higher thermal conductivity is assumed to generate stronger ground heat flux entering the soil. However, Fig. 9e shows that the ground heat flux in the M10 simulations is nearly $40 \mathrm{Wm}^{-2}$ lower than in the MOD run when SWC is at $17 \%$. In fact, ground heat flux in MMC is calculated as the residual of the soil surface energy budget. When upward surface latent heat flux is dominant, the heat flux entering the soil is weakened, which explains the weaker ground heat flux in the M10 simulations, even though the soil thermal conductivity in these simulations is higher than in the MOD run.

Therefore, irrigation leads to a strong cooling of the cropland surface and near surface during the day. Such cooling results from the strong evaporation related to 


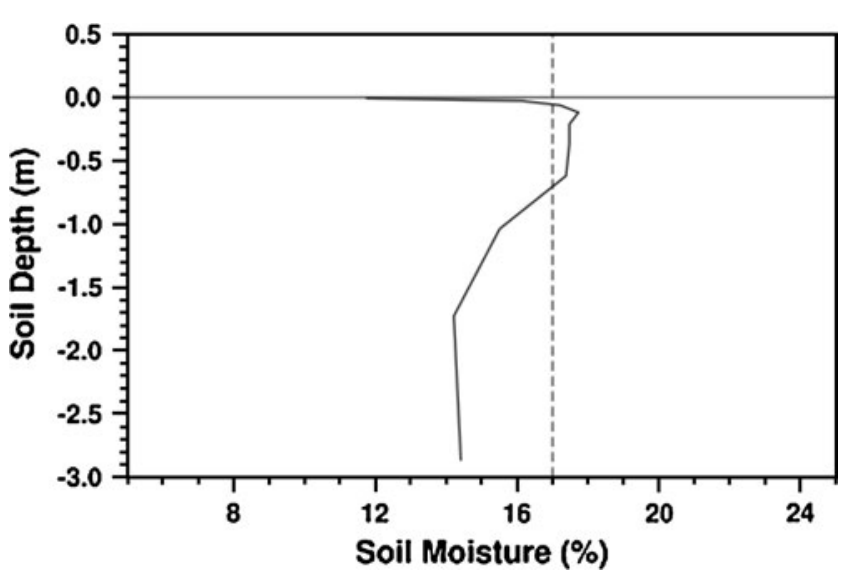

Fig. 10 Vertical SWC profile (curved solid line) averaged over the spring and summer of 1996 from the MOD simulation. The solid horizontal line is the soil surface, and the dashed vertical line is the position of the 1-m SWC average from the MOD simulation for the spring and summer of 1996

irrigation. This daytime irrigation cooling intensifies the near-surface cooling caused by the land use change from the savanna-tree land type to cropland in the California Central Valley, and can override the surface warming resulting from the same land use change in this region during fall, spring, and summer, based on our modeling results (Fig. 5b).

\subsubsection{Tmin}

Similar to the Tmax analysis, the latent, sensible, and ground heat fluxes at Tmin in the M10 simulations change significantly as the SWC varies from 3\% to 30\% (Fig. 11). Changes in the radiation forcing are still quite minor (figures not shown). Figure 11 shows that the nighttime temperature and heat flux do not change monotonically when increasing the SWC from 3\% to $30 \%$ (except for evaporation), due to interactions among the heat fluxes. However, the M10 Tmin and Tgn with irrigation (SWC $>17 \%$ ) are lower than those in the MOD run. The temperature changes are closely related to evaporation, which increases from 4 to $9 \mathrm{Wm}^{-2}$ when increasing the SWC from $17 \%$ to $30 \%$. Thus, irrigation also has a cooling effect during the night.

As shown in Fig. 6, land use change results in a nighttime warming of $0.55^{\circ} \mathrm{C}$ for the near-surface air averaged over the spring and summer irrigation period. However, when SWC is between $17 \%$ and $19 \%$, irrigation causes only about a $0.3^{\circ} \mathrm{C}$ to $0.5^{\circ} \mathrm{C}$ reduction in nearsurface air temperature. Thus, such minor irrigationrelated cooling cannot overwhelm the near-surface air warming that result from land surface change in the Central Valley. The net effect of both land use change and irrigation is that the near- surface air still shows warming. When irrigation becomes more intense (e.g., SWC $>19 \%$ ), such a net effect will show cooling for the near-surface air based on our simulations.

\section{Conclusions and discussion}

This study uses high-quality observations and a sophisticated regional climate model to perform detailed analyses on how land use change and irrigation affect the local daily minimum and maximum temperatures in the Central Valley, where land use types have changed from savannas and trees to crops since presettlement. The land use data is based on the GLCC land use types. The observed analysis indicates that over the San Joaquin Valley, Tmax has decreased and Tmin has increased during the last century. These temperature changes are likely the combined consequence of global climate change, land use change, and irrigation. The objective of the present study is to use our modeling tools to isolate the role of land use change and irrigation from that of global climate change to understand temperature changes and to quantify the detailed physical processes of the impact of the former two events. Our modeling results indicate that with only land use change being included in the MMC model over a portion of the Central Valley that changed from the savanna-tree land type to cropland, Tmax decreases, and Tmin increases over all four seasons without irrigation, which is consistent with observations. The decrease in Tmax results from a weaker sensible heat flux. The weakened sensible heat is caused by the lower surface roughness length, as a result of the removal of presettlement savannas and trees and their replacement with crops and bare soil. When compared to the PRE simulations, the Tmin in the MOD simulations increases; this increase is caused by a higher sensible heat flux that results from the intensified turbulence due to stronger winds. The stronger winds are induced by the lower roughness length in the MOD run.

Irrigation lowers surface temperature, which in turn reduces the sensible heat flux during the day as compared with nonirrigated cropland. The decreased surface temperature is caused by stronger surface evaporation as a result of manually adding water during irrigation. Both the lowered sensible heat flux and decreased surface temperature strengthen the Tmax reduction that is caused by land use change. During the night, irrigation also produces stronger surface evaporation, which cools the surface, weakens the sensible heat flux, and further reduces Tmin. In our defined irrigation zone, where the SWC values are above the average value during the spring and summer irrigation period $(17 \%)$, the nighttime near-surface air over the modern-day irrigated cropland is warmer than over the savanna-tree land during presettlement only when light irrigation is applied (e.g., $17 \%<\mathrm{SWC}<19 \%$ ). When the 

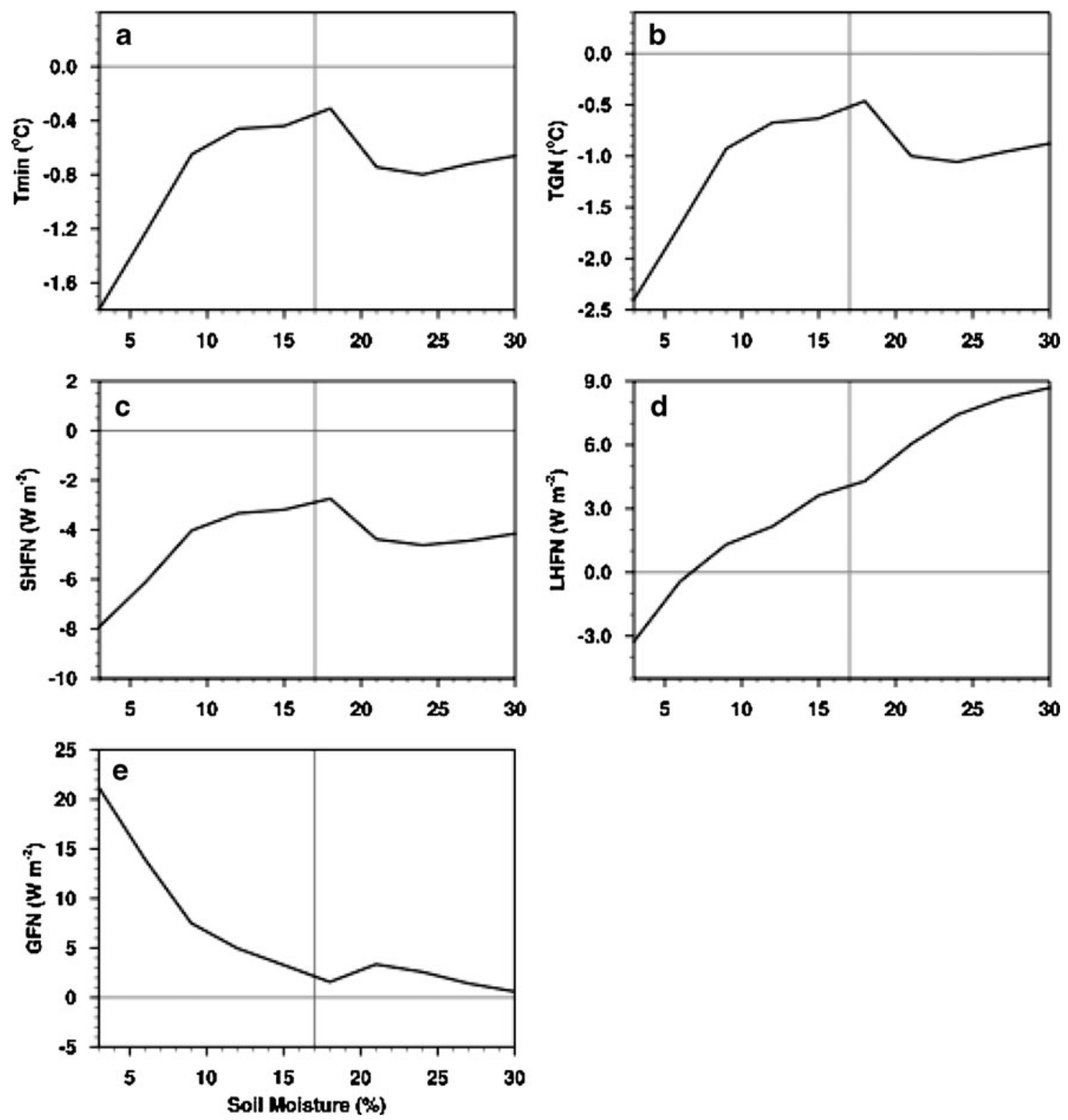

Fig. 11 Temperature and heat flux differences versus SWC between the M10 ensemble simulations and the MOD simulation (M10-MOD) averaged over the spring and summer of 1996. a Tmin, b Tgn, c

sensible heat flux, $\mathbf{d}$ latent heat flux, e ground heat flux. The solid vertical line is the position for the 1-m averaged SWC in the MOD run for the same period

SWC is greater than $19 \%$, the nighttime near-surface air is colder. These results are based on our model simulations. In this study, we provide only a range of possibilities indicating the role of irrigation processes that affect regional climate. However, this needs to be further evaluated with detailed observations.

Another process affecting Central Valley temperature changes could be global warming. In our simulations, the lateral boundary forcing conditions for both the MOD and PRE runs are exactly the same without considering the global warming impact. However, global warming is likely a strong factor that results in a sustained upward trend for

the observed Tmin during the night. For a more detailed understanding of how global climate change contributes to temperature changes over irrigated croplands, multiyear model simulations with dynamic carbon forcing are needed. In addition, the land use change discussed in this study is a typical example of agricultural expansion across much of the global land surface, where the land cover changes from natural grassland and forest (savanna and tree) to cropland and bare soil. Thus, the methodologies and derived physical processes presented here could be used to better understand temperature variations with similar land use changes elsewhere. 
Acknowledgments We are very grateful to John Christy from the University of Alabama in Huntsville for useful discussions and for providing us with San Joaquin Valley near-surface air temperature observations. Jiming Jin was supported by the Utah Agricultural Experiment Station, USDA Special Grants No. 2008-34610-19175, No. 2009-34610-19925, and EPA RD83418601.

Open Access This article is distributed under the terms of the Creative Commons Attribution Noncommercial License which permits any noncommercial use, distribution, and reproduction in any medium, provided the original author(s) and source are credited.

\section{References}

Bonan GB (1996) A land surface model (LSM version 1.0) for ecological hydrological and atmospheric studies: technical description and user's guide. NCAR Technical Note NCAR/TN417+STR. National Center for Atmospheric Research, Boulder

Bonfils C, Lobell D (2007) Empirical evidence for a recent slowdown in irrigation-induced cooling. Proc Natl Acad Sci 104(34):13582-13587

Christy RC, Norris WB, Redmond K, Gallo KP (2006) Methodology and results of calculating central California surface temperature trends: evidence of human-induced climate change? J Climate 19:548-563

Costa MH, Botta A, Cardille JA (2003) Effects of large-scale changes in land cover on the discharge of the Tocantins River, southeastern Amazonia. J Hydrol 283:206-217

Dickinson RE (1983) Land surface processes and climate-surface albedos and energy balance. Advances in Geophysics. Academic Press, 48 pp

Dickinson RE, Henderson-Sellers A, Kennedy PJ (1993) Biosphere Atmosphere Transfer Scheme (BATS) Version 1e as Coupled to the NCAR Community Climate Model. NCAR Technical Note, NCAR/TN-387+STR, 72 pp.

Diffenbaugh NS (2009) Influence of modern land cover on the climate of the United States. Clim Dyn 33(7-8):945-958

Dudhia J (1989) Numerical study of convection observed during winter monsoon experiment using a mesoscale two-dimensional model. J Atmos Sci 46:3077-3101

Feddema JJ, Oleson KW, Bonan GB, Mearns LO, Buja LE, Meehl GA, Washington WM (2005) The importance of land cover change in simulating future climates. Science 310:1674-1678

Foley JA, DeFries R, Asner GP, Barford C, Bonan GB, Carpenter SR, Chapin FS, Coe MT, Daily GC, Gibbs HK, Helkowski JH, Holloway T, Howard EA, Kucharik CJ, Monfreda C, Patz JA, Prentice IC, Ramankutty N, Snyder PK (2005) Global consequences of land use. Science 309:570-574

Grell G (1993) Prognostic evaluation of assumptions used by cumulus parameterizations. Mon Weather Rev 121:764-787

Grell G, Dudhia J, Stauffer D (1994) A description of the fifthgeneration Penn State/NCAR Mesoscale Model (MM5). NCAR Tech. Note NCAR/TN-398+STR, 117 pp.

Guo Z, Xiao X, Li D (2000) An assessment of ecosystem services: water flow regulation and hydroelectric power production. Ecol Appl 10(3):925-936. doi:10.2307/2641057

Hack JJ, Boville BA, Briegleb BP, Kiehl JT, Rasch PJ, Williamson DL (1993) Description of the NCAR Community Climate Model (CCM2). NCAR Tech. Note NCAR/TN-3821STR.

Hansen J, Sato M, Ruedy R, Lo K, Lea DW, Medina-Elizade M (2006) Global temperature change. Proc Natl Acad Sci 103:14288-14293
Hayhoe K, Cayan D, Field CB, Frumhoff PC, Maurer EP, Miller NL, Moser SC, Schneider SH, Cahill KN, Cleland EE, Dale L, Drapek R, Hanemann RM, Kalkstein LS, Lenihan J, Lunch CK, Neilson RP, Sheridan SC, Verville JH (2004) Emissions pathways, climate change, and impacts on California. Proc Natl Acad Sci 101:12422-12427

Hong S-Y, Pan H-L (1996) Nonlocal boundary layer vertical diffusion in a medium-range forecast model. Mon Weather Rev 124:2322-2339

Houghton JT, Ding Y, Griggs DJ, van der Linden PJ, Dai X, Maskell K, Johnson CA (2001) Climate change 2001: the scientific basis. Contribution of Working Group I to the Third Assessment Report of the Intergovernment Panel on Climate Change, $881 \mathrm{pp}$.

Jin J, Miller NL (2010) Snow simulation improvement in a regional climate model. Submitted to Hydrological Processes (in review)

Jin J, Miller NL, Sorooshian S, Gao X (2006) Relationship between atmospheric circulation and snowpack in the western United States. Hydrol Process 20(4). doi:10.1002/hyp.6126

Kanamitsu M, Ebisuzaki W, Woollen J, Yang SK, Hnilo JJ, Fiorino M, Potter GL (2002) NCEP-DOE AMIP-II reanalysis (R-2). Bull Am Meteorol Soc 83:1631-1643

Karl TR, Coauthors (1993) A new perspective on recent global warming: asymmetric trends of daily maximum and minimum temperature. Bull Am Meteorol Soc 74:1007-1023

Kueppers LM, Snyder MA, Sloan LC (2007) Irrigation cooling effect: regional climate forcing by land-use change. Geophys Res Lett 34(3):L03703. doi:03710.01029/02006GL028679

Kueppers LM, Snyder MA, Sloan LC, Cayan DR, Jin J, Kanamaru H, Kanamitsu M, Miller NL, Tyree M, Du H, Weare BC (2008) Multi-model comparison of the climate response to land-use change in the western United States. Glob Planet Change. doi:10.1016/J.GLOPLACHA.2007.1003.1005

Lee E, Chase TN, Rajagopalan B, Barry RG, Biggs TW, Lawrence PJ (2009) Effects of irrigation and vegetation activity on early Indian summer monsoon variability. Int J Climatol 29(4):573-581

Lobell DB, Bala G, Duffy PB (2006) Biogeophysical impacts of cropland management changes on climate. Geophys Res Lett 33 (6):L06708. doi:06710.01029/02005GL025492

Loveland TR, Reed BC, Brown JF, Ohlen DO, Zhu Z, Yang L, Merchant JW (2000) Development of a global land cover characteristics database and IGBP DISCover from $1 \mathrm{~km}$ AVHRR data. Int J Remote Sens 21(6 \& 7):1303-1330

Oleson KW, Dai Y, Bonan GB, Bosilovich M, Dickinson RE, Dirmeyer P, Hoffman F, Houser P, Levis S, Niu G-Y, Thornton P, Vertenstein M, Yang Z-L, Zeng X (2004) Technical description of the community land model (CLM), NCAR/TN461+STR, $174 \mathrm{pp}$

Olson JS (1994) Global ecosystem framework-definitions: USGS EROS Data Center Internal Report, Sioux Falls, SD, 37 pp

Qian Y, Leung LR, Ghan SJ, Giorgi F (2003) Regional climate effects of aerosols over China: modeling and observation. Tellus B 55 (4):914-934

Sacks WJ, Cook BI, Buenning N, Levis S, Helkowski JH (2009) Effects of global irrigation on the near-surface climate. Clim Dyn 33(2-3):159-175

Sellers PJ (1985) Canopy reflectance, photosynthesis and transpiration. Int J Remote Sens 6:1335-1372

Snyder PK, Delire C, Foley JA (2004) Evaluating the influence of different vegetation biomes on the global climate. Clim Dyn 23:279-302. doi:10.1007/s00382-004-04300

Wilkinson R, Clarke K, Reichman J, Dozier J (2002) Preparing for a changing climate: the potential consequences of climate variability and change for California, $850 \mathrm{pp}$ 